\title{
Sistem Informasi Pengukuran Efektivitas Mesin Kemas Dengan Metode Overall Effectiveness (OEE) Pada PT Finusolprima Farma Internasional
}

\author{
Andre Farezy $\mathrm{P}^{1, *}$, Muhamad Baydhowi ${ }^{2}$, \\ ${ }^{1}$ Sistem Informasi; Universitas Bina Insani; Universitas Bina Insani; JI. Siliwangi No. 6 Rawa \\ Panjang Bekasi Timur Kota Bekasi 17114 Indonesia, Telp. (021) 82436886 / (021) 82436996. \\ Fax. (021) 824009 24; e-mail: andreandrefarezyfarezy@gmail.com, \\ muhamadbaydhowi@gmail.com \\ * Korespondensi: e-mail: muhamadbaydhowi@gmail.com
}

Diterima: 12 Januari 2022; Review: 21 Januari 2022; Disetujui: 28 Januari 2022

Cara sitasi: Farezy A, Baydhowi M. 2021. Sistem Informasi Pengukuran Efektifitas Mesin Kemas Dengan Metode Overall Equipment Effectiveness (OEE) Pada PT Finusolprima Farma Internasional. Information Management for Educators and Professionals. Vol.6 (1): 51-60.

\begin{abstract}
Abstrak: Pengemasan sekunder merupakan salah satu cara yang digunakan untuk melindungi obat dari lingkungan sekitarnya sehingga kualitas dari obat dapat tetap terjaga hingga nanti sampai ke konsumen. Produktivitas suatu proses pengemasan sekunder dapat ditingkatkan/dipertahankan dengan melakukan evaluasi rutin terhadap prosesnya. Evaluasi yang dilakukan adalah dengan analisis OEE (Overall Equipment Effectiveness). OEE merupakan suatu metode perhitungan yang digunakan untuk mengetahui efektivitas suatu proses yang sedang dilaksanakan dengan mengidentifikasi persentase waktu produksi yang benar-benar produktif yang dipengaruhi oleh tiga faktor, yaitu availability, performance, dan quality. Penelitian dilakukan dengan mengamati proses pengisian OEE yang masih menggunakan form tertulis dimana hal ini banyak memakan waktu dari segi pengisian hingga transaksi penyerahan berkas dan pengisian Kembali yang dilakukan oleh admin untuk dapat menyimpulkan keseluruhan data. oleh sebab itu diperlukan teknologi informasi untuk membantu memperingkas aktivitas tersebut sehingga tidak diperlukannya lagi adanya pengisian secara manual pada sebuah form yang dilakukan operator dan transaksi penyerahan berkas terhadap admin dan pengisian data ulang yang dilakukan oleh admin dari form ke file.
\end{abstract}

Kata kunci: Efektivitas, Pengukuruan, Sistem Informasi, Mesin Kemas, Metode Overall Effectiveness

\begin{abstract}
Secondary packaging is one of the methods used to protect drugs from the surrounding environment so that the quality of the drugs can be maintained until they reach consumers. The productivity of a secondary packaging process can be increased / maintained by regular evaluation of the process. The evaluation is carried out by means of OEE (Overall Equipment Effectiveness) analysis. OEE is a calculation method used to determine the effectiveness of a process that is being implemented by identifying the percentage of production time that is truly productive which is influenced by three factors, namely availability, performance, and quality. The research was conducted by observing the OEE filling process which still used a written form, which took a lot of time from the point of view of filling in to file submission transactions and replenishment by the admin to be able to conclude the entire data. Therefore, information technology is needed to help streaamline these activities so that there is no need for manual filling in a form by operators and file submission transactions to the admin and replenishment of data performed by the admin from form to file.
\end{abstract}

Keywords: Effectiveness, Measurement, Information Systems, Packaging Machines, Overall Effectiveness Method 


\section{Pendahuluan}

Kebutuhan cairan infus injeksi untuk pengobatan selalu mengalami perkembangan. Hal ini sangat didukung dari segi proses produksinya. Untuk menentukan apakah kualitas proses produksi sudah memenuhi persyaratan, perusahaan memiliki standar yang telah ditetapkan. Jika kualitas produk yang dihasilkan diluar dari standar tersebut, maka perusahaan harus segera menangani hal tersebut dan mengembalikan kualitas produk ke dalam standar yang memenuhi persyaratan untuk menghindari kerugian yang berkelanjutan. Kualitas produk yang tidak sesuai dengan standar tersebut bisa disebabkan oleh berbagai hal mulai dari operator, mesin, lingkungan kerja, maupun bahan atau alat yang digunakan pada proses produksinya. Hal ini sangat menuntut perusahaan untuk melakukan perbaikan dengan dimulai dari mencari akar permasalahan yang ada. Untuk menentukan akar permasalahan tersebut PT Finusolprima Farma Internasional sudah menggunakan metode OEE untuk menemukan akar dari permasalahan atas kecurigaan kecurigaan yang timbul dan berpotensi bisa menurunkan hasil produksi, tetapi dalam implementasi penerapan metode OEE tersebut masih ada beberapa tahapan sistem yang masih menggunakan cara manual seperti pengisian formular OEE kemas yang nantinya akan diserahkan ke admin dan admin akan menginputnya kembali kedalam file dimana semua kegiatan tersebut membutuhkan waktu yang tidak sebentar. Sistem OEE yang berjalan masih bisa di optimalkan lagi untuk menunjang intergritas serta memanfaatakan ke efektifitasan sistem tersebut dengan membungkusnya dalam sistem yang sudah terkomputerisasi.

Sistem

Mempelajari suatu sistem akan lebih mengena bila mengetahui terlebih dahulu apakah sistem itu. Pengertian sistem pertama kali dapat diperoleh dari definisi sistem itu sendiri, menyimpulkan bahwa: suatu sistem pada dasarnya adalah sekelompok unsure erat hubungannya satu dengan yang lain, yang berfungsi Bersama-sama untuk mencapai tujuan tertentu[1].

Informasi

Pengertian informasi masih bersifat kontradiktif dan belum mempunyai ciri-ciri khusus. Maka para pakar teori atau ilmu pengetahuan informasi belum dapat membut satu deifinisi yang jelas dan lengkap mengenai apa yang disebut informasi. Pada umumnya informasi dipandang dari sudut arti dan isi yang di dalamnya. Informasi diserap dan disediakan pada anggapan bahwa penerima lebih baik diberiahu, misalnya fungsi utama Pendidikan adalah menyebarkan informasi, sedangkan bagi pustakawan fungsi informasi terletak pada refrensi, arsip informasi setempat, atau dengan kata lain informasi berasal dari fakta, data, pendapat, dan kejadian yang sesungguhnya. [2]

Data

Pengertian data menurut Webster New World Dictionary, Data adalah things or assumed, yang berarti bahwa data itu sesuatu yang diketahui atau dianggap. Diketahui artinya yang sudah terjadi merupakan fakta (bukti). Data dapat memberikan gambaran tentang suatu keadaan atau persoalan.[3]

Pengukuran

Definisi atau pengertian pengukuran (measurement) adalah suatu kegiatan ilmiah yang dilakukan untuk mengukur atau membandingkan nilai suatu besaran dengan satuan ukur tertentu. Dalam kamus Besar Bahasa Indonesia (KKBI), pengukuran diartikan sebagai proses, cara, atau perbuatan pengukuran.[4]

Metode

Metode yang merupakan cara kerja ilmiah yang secara teknis dipergunakan sebagai alat atau sarana (a tool) dalam suatu penelitian. Dapat dikaitkan bahwa metode lebih menekankan pada aspek teknis penelitian, sehingga fungsinya sangat urgen dalam suatu pelaksanaan penelitian.[5]

\section{Overall Equipment Effectiveness (OEE)}

OEE adalah metode yang banyak dipakai oleh perusahaan-perusahaan besar di seluruh dunia dengan harapan dapat mendongkrak kinerja perusahaan dalam aspek teknis pencapaian produksinya. Seiring membaiknya kinerja proses produksi maka target-target produksi akan terpenuhi dan pada akhirnya akan memberikan sumbangsih besar terhadap tujuan besar perusahaan tersebut secara keseluruhan.[6] 


\section{Hypertext Preprocessor (PHP)}

PHP singkatan dari PHP: Hypertext Preprocessor yaitu bahasa pemograman web serverside yang bersifat open source. PHP merupakan script yang terintegrasi dengan HTML dan berada pada server (server side HTML embedded scripting). PHP adalah script yang digunakan untuk membuat halaman website yang dinamis. Dinamis berarti halaman yang akan ditampilkan dibuat saat halaman itu diminta oleh client. Mekanisme ini menyebabkan informasi yang diterima client selalu yang terbaru/up to date. Semua script PHP dieksekusi pada server dimana script tersebut dijalankan.[7]

\section{Website}

Web merupakan kumpulan halaman-halaman web yang berhubungan dengan komponen perangkat lunak yang terkait secara semantis dengan konten dan secara sintaktis melalui tautan dan mekanisme control lainnya, Situs web dapat bersifat dinamis dan interaktif. Suatu aplikasi web merupakan program yang yang berjalan di dalam keseluruhan atau pada Sebagian server web dan dapat dijalankan oleh pengguna melalui situs web.[8]

\section{Metode Penelitian}

Teknik pengumpulan data yang digunakan dalam penulisan ini adalah sebagai berikut: Pertama: Observasi yang dilakukan dengan cara datang langsung ke PT FINUSOLPRIMA FARMA INTERNASIONAL. Dengan beberapa acuan yaitu menganalisa beberapa dokumen pendukung yang terkait kedalam Analisa pengisian OEE. Melihat jarak tempuh dari area kemas menuju area admin dan melihat potensi potensi lain yang bisa menyebabkan hal-hal yang tidak di inginkan. PT FINUSOLPRIMA FARMA INTERNASIONAL berada di kota Bekasi tepatnya berada di Jl. Raya Bekasi Km 28,5 Kawasan Industri Rawa Pasung, Kota Baru Bekasi Barat, dan memiliki total karyawan 232 karyawan yang terbagi-bagi dalam beberapa departement yang peletakan gedungnya terpisah satu dengan lainnya dan untuk department produksi berada di area gedung belakang dengan jumlah 84 karyawan. Kedua, melakukan wawancara dengan Bapak Rony Hermansyah selaku operator kemas dan Ibu Celestial selaku admin yang bertugas menginput data. Ketiga, melakukan studi Pustaka dengan mengumpulkan data dari buku beserta jurnal yang berkaitan dengan pengukuran mesin dengan metode OEE dan semua informasi dengan penelitian yang dilakukan.

Metode Pengembangan Sistem yang digunakan adalah metode air terjun (waterfall). Metode tersebut merupakan model sebuah siklus hidup yang terdiri dari mulai fase hidup perangkat lunak sebelum terjadi hingga pascaproduksi. Waterfall model memiliki definisi sendiri bahwa sebuah hidup perangkat lunak memiliki sebuah proses yang linear dan sekuensial[9].Tahapan metode waterfall dapat dilihat pada gambar 1 :

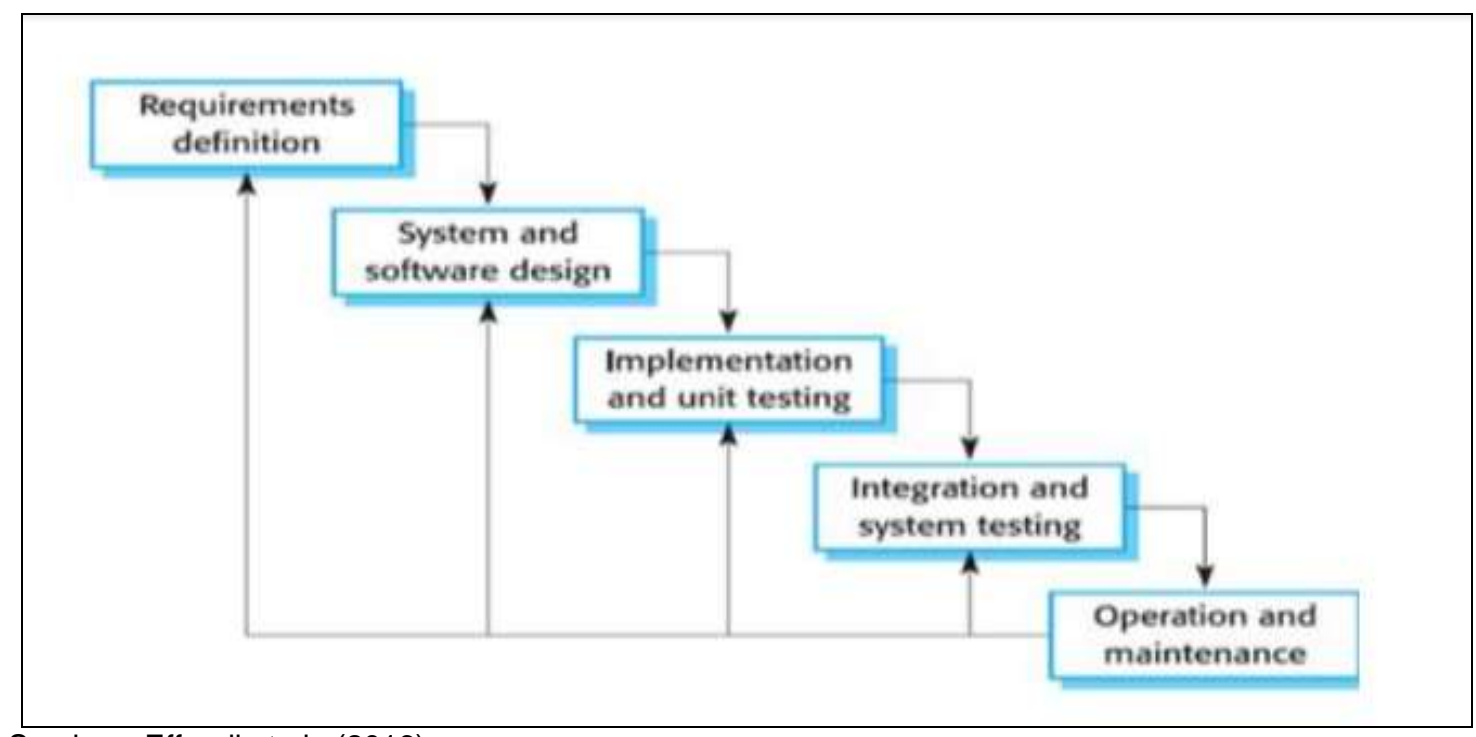

Sumber : Effendi et al., (2016)

Gambar 1. Metode Waterfall 
Berdasarkan gambaran pada Gambar 1 metode waterfall, terdapat beberapa tahapan sebagai berikut: 1). Requirements analysis and definition, Layanan sistem, kendala, dan tujuan ditetapkan oleh hasil konsultasi dengan pengguna yang kemudian didefinisikan secara rinci dan berfungsi sebagai spesifikasi sistem. Analisis kebutuhan dilakukan dengan cara mewawancarai operator kemas dan admin. Dari wawancara didapatkan data-data cara perhitungan OEE, seperti : Availability yang terdiri dari Breakdowns dan Setup/Adjustments, Performance yang terdiri dari Small Stop dan Slow Running, Quality yang terdiri dari Setup Defects dan Production Defect. 2). System and software design, Tahapan perancangan sistem mengalokasikan kebutuhan-kebutuhan sistem baik perangkat keras maupun perangkat lunak dengan membentuk arsitektur sistem secara keseluruhan. Perancangan perangkat lunak melibatkan identifikasi dan penggambaran abstraksi sistem dasar perangkat lunak dan hubungannya.

Percancangan sistem menggunakan UML seperti Use Case dan Squance, 3). Implementation and unit testing, pada tahap ini, perancangan perangkat lunak direalisasikan sebagai serangkaian program atau unit xprogram. Pengujian melibatkan verifikasi bahwa setiap unit memenuhi spesifikasinya. Sistem informasi akan dibuat menggunakan bahasa pemrograman PHP dengan Framework Codelgninter, 4). Integration and system testing

Unit-unit individu program atau program digabung dan diuji sebagai sebuah sistem lengkap untuk memastikan apakah sesuai dengan kebutuhan perangkat lunak atau tidak. Setelah pengujian, perangkat lunak dapat dikirimkan ke customer, Pengujian dilakukan pada aspek fungsionalitas kepada user yaitu operator dan admin, 5). Operation and maintenance

Biasanya (walaupun tidak selalu), tahapan ini merupakan tahapan yang paling panjang. Sistem dipasang dan digunakan secara nyata. Pemeliharaan akan dilakukan apabila ada update fitur atau memperbaiki kesalahan yang ditemukan pada saat sistem digunakan langsung oleh user.[10]. Kerangka pemikiran merupakan tahapan-tahapan yang digunakan dalam penelitian. Adapun bentuk kerangka pemikiran yang digunakan dapat dilihat pada Gambar 2.

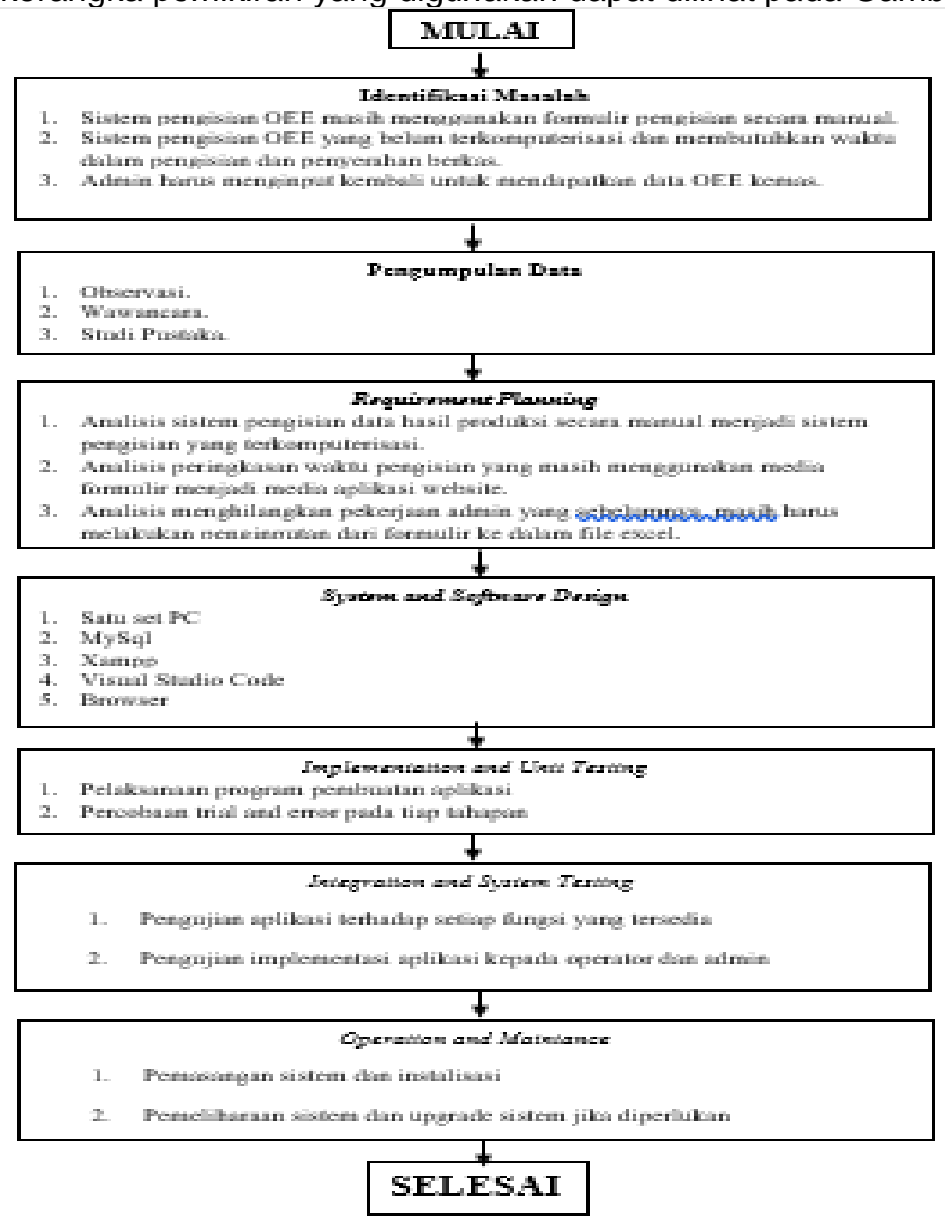

Sumber : Hasil Penelitian (2021)

Gambar 2. Kerangka Pemikiran 


\section{Hasil dan Pembahasan}

Berdasarkan hasil pengamatan dan observasi yang di lakukan,maka berikut ini adalah gambaran sistem yang berjalan dari proses pengukuran mesin kemas dengan menggunakan metode OEE yang dilakukan oleh operator kemas yang bertugas mengisi laporan harian produksi sampai penyerahan data hasil OEE kepada admin produksi dan admin akan menginput Kembali data hasil OEE ke dalam excel lalu menyerahkan data kepada supervisor, adapun gambarannya dapat dilihat pada gambar 3 .

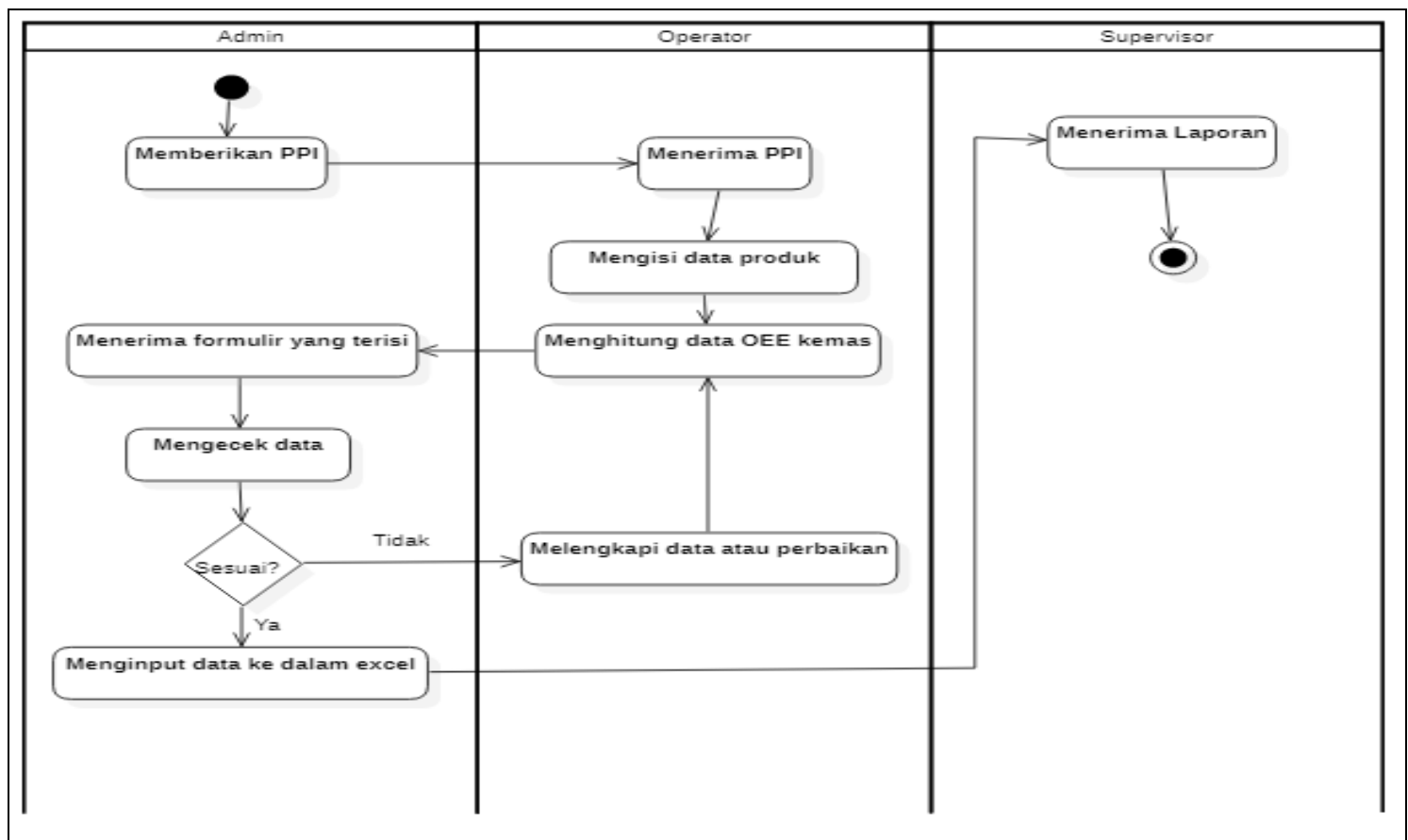

Sumber : Hasil Penelitian (2021)

Desain

Gambar 3. Activity Diagram Proses Bisnis

Dalam pembuatan sistem aplikasi perlu merancang basis data (Database) hingga terbentuk struktur tabel sistem informasi pengukuran mesin kemas dengan metode OEE. Setiap atribut bukan kunci haruslah bergantung hanya pada primary key secara menyeluruh. Berikut adalah bentuk normalisasi ketiga yang dapat dilihat pada gambar 4 :

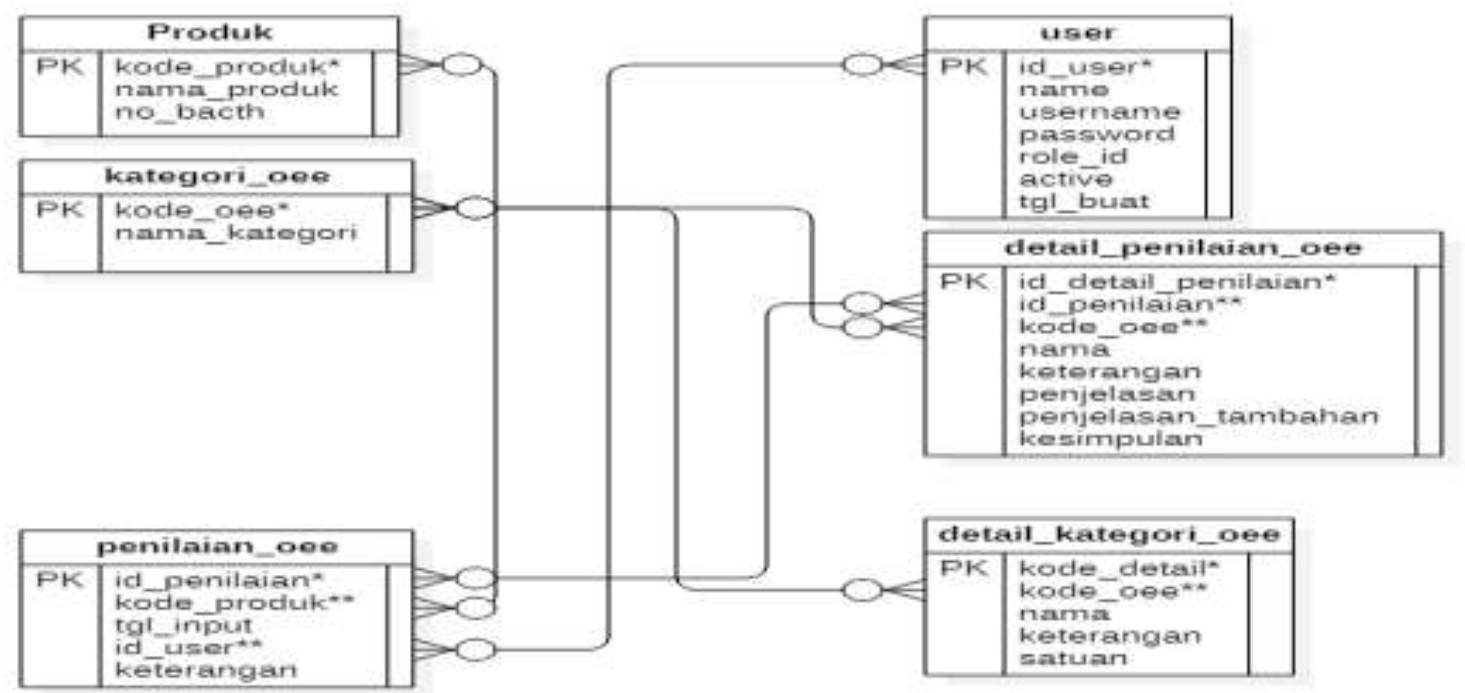

Sumber : Hasil Penelitian (2021)

Gambar 4. Bentuk Thrid Normal Form 
Use case diagram adalah menggambarkan tentang cara user berkomunikasi dengan sistem yang berjalan dan berfungsi untuk mengetahui fungsi-fungsi yang ada didalam sistem, berikut adalah proses usulan dengan usecase diagram, yang dapat dilihat pada gambar 5 :

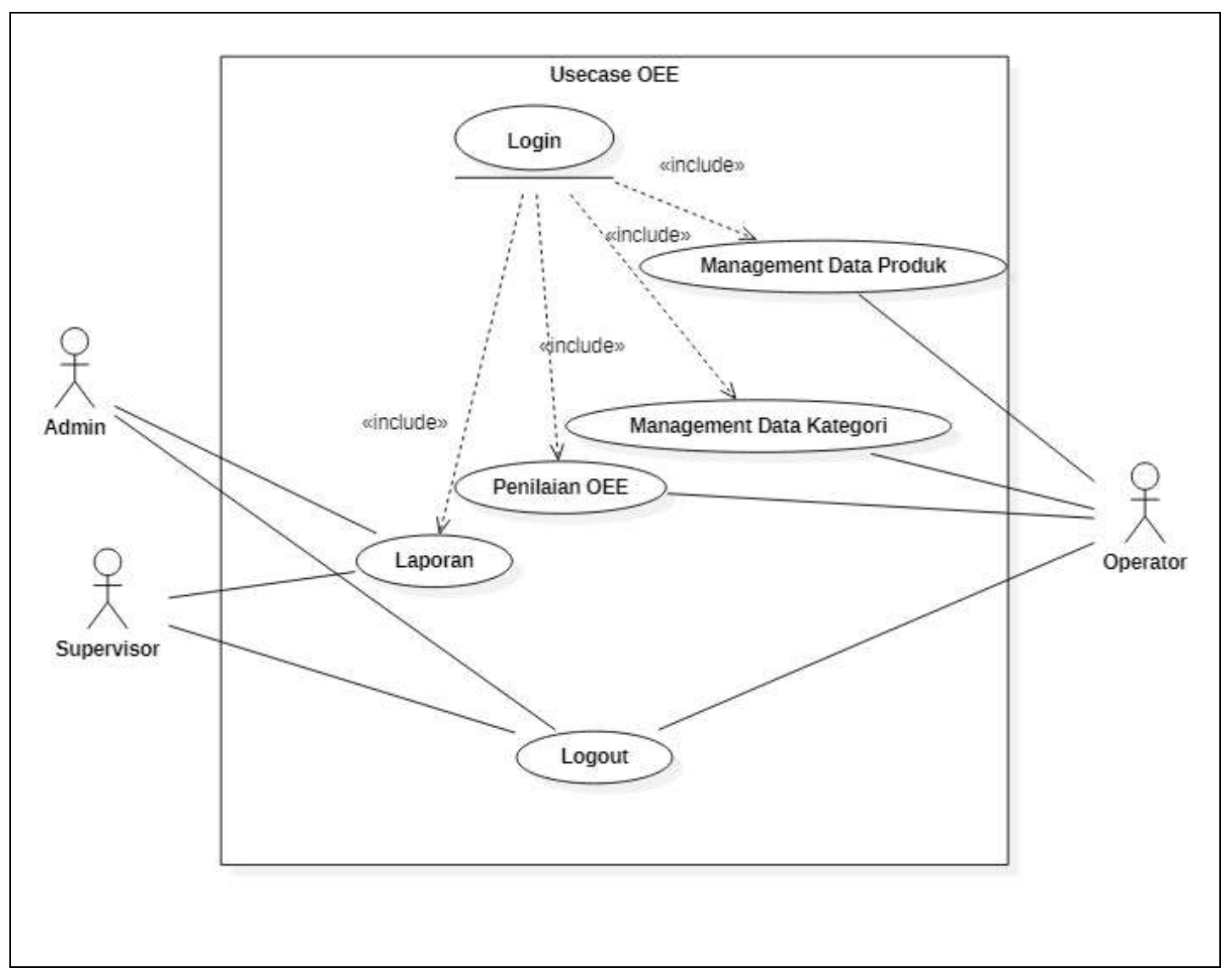

Sumber : Hasil Penelitian (2021)

Gambar 5. Use Case Diagram

Pada skenario akan dijelaskan tentang apa yang akan dilakukan sistem saat aktor melakukan aktivitas. Berikut merupakan skenario Penilaian Produk, yang dapat dilihat pada tabel 1:

Table 1. Secenario Use Case Penilaian Produk

\section{Identifikas}

\begin{tabular}{|c|c|}
\hline & Pengukuran Mesin Kemas dengan Metode OEE \\
\hline Aktor & Operator, Admin, Supervisor \\
\hline Deksripsi & $\begin{array}{l}\text { Use Case menggambarkan aktor masuk kedalam halaman menu, dan } \\
\text { dapat melihat data hasil penilain OEE }\end{array}$ \\
\hline \multicolumn{2}{|r|}{ Skenario Utama } \\
\hline Aksi Aktor & Reaksi Sistem \\
\hline $\begin{array}{l}\text { 1. Mengisi form login, lalu klik } \\
\text { "Masuk" }\end{array}$ & $\begin{array}{l}\text { 2. Menampilkan data penilaian } O E E \text { yang sudah dikerjakan dengan } \\
\text { status sesuai hasil pencapain }\end{array}$ \\
\hline $\begin{array}{l}\text { 3. Mengklik tambah produk membuat } \\
\text { produk baru yang akan di beri } \\
\text { penilaian }\end{array}$ & $\begin{array}{l}\text { 4. Menampilkan data produk yang berisi keterangan, kesimpulan dan } \\
\text { hasil pencapain yang didapat pada hari produksi tersebut }\end{array}$ \\
\hline $\begin{array}{l}\text { 5. Memilih detail produk yang ingin } \\
\text { ditampilkan }\end{array}$ & $\begin{array}{l}\text { 6. Menampilkan data produk yang tersedia beserta keterangan } \\
\text { keterangan pada produk tersebut }\end{array}$ \\
\hline $\begin{array}{l}\text { 7. Memilih penilaian untuk } \\
\text { memberikan nilai pada produk }\end{array}$ & $\begin{array}{l}\text { 8. Menampilkan data produk yang tersedia dan siap dilakukan penilaian } \\
\text { untuk mendapatkan hasil } O E E\end{array}$ \\
\hline $\begin{array}{l}\text { 9. Jika role “Admin" maka dapat } \\
\text { melakukan download data laporan }\end{array}$ & $\begin{array}{l}\text { 10. Menampilkan data ketersedian produk yang siap di cetak menjadi } \\
\text { laporan dalam bentuk excel }\end{array}$ \\
\hline Kondisi Akhir & Aktor melihat halaman menu \\
\hline
\end{tabular}

Sumber : Hasil Penelitian (2021) 
Activity Diagram adalah menggambarkan alur kerja sistem, berikut adalah bentuk dari sistem usulan activity diagram pada proses penilaian produk, yang dapat dilihat pada gambar 6 :

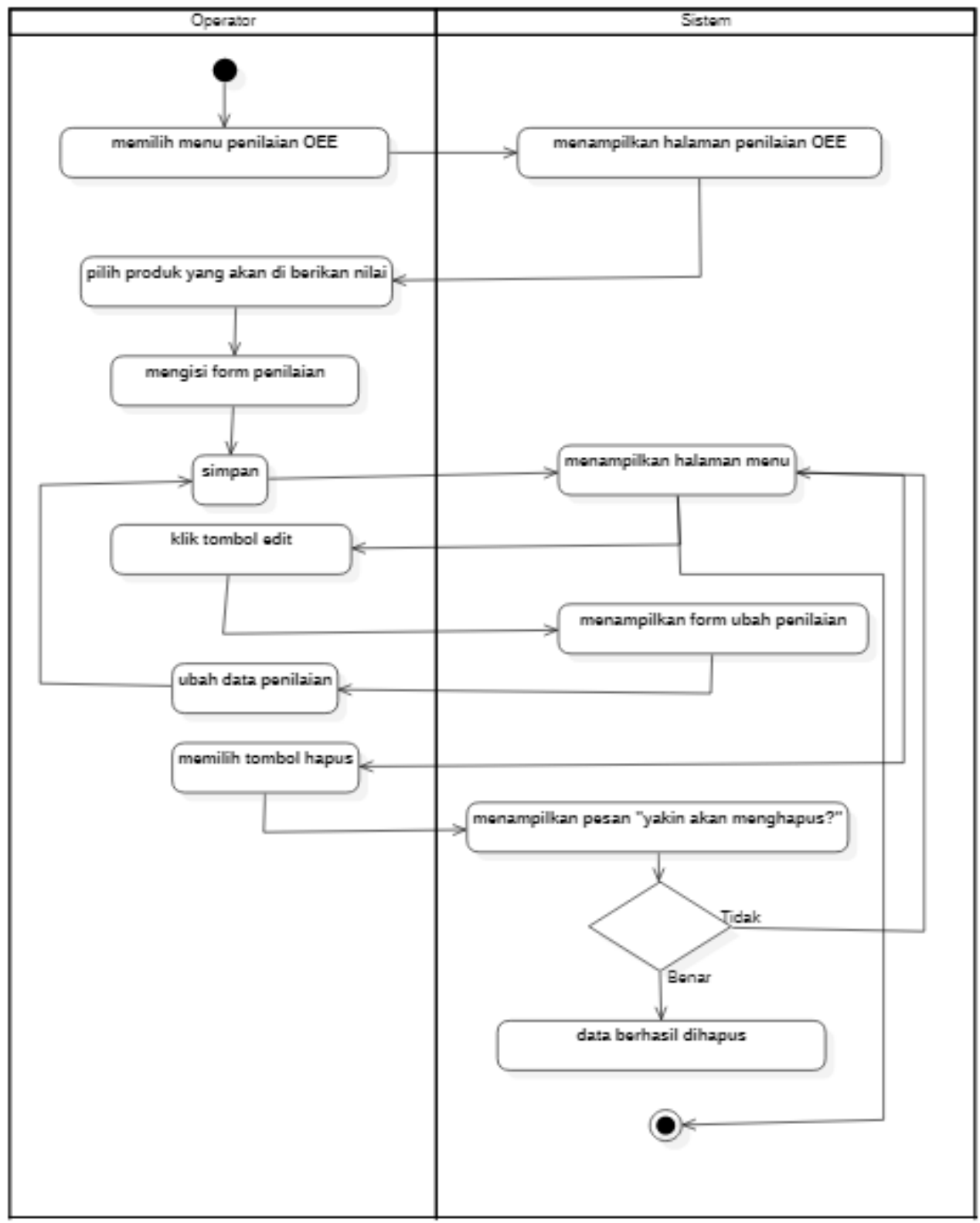

Sumber : Hasil Penelitian (2021)

Gambar 6. Activity Diagram Penilaian Produk

\section{Hasil Implementasi}

Aplikasi sistem informasi pengukuran mesin kemas menggunakan metode OEE diimplementasikan ke dalam aplikasi berbasis web. antarmuka aplikasi menggunakan framework Codeigniter 3.0 dan tambahan bootstrap untuk mempermudah dan mempercepat pengembangan pada bagian user interface serta bahasa pemrograman PHP sebagai penghubung dengan database. Tampilan user interface dapat dilihat pada tabel 2 berikut: 
Table 2. Tampilan user interface

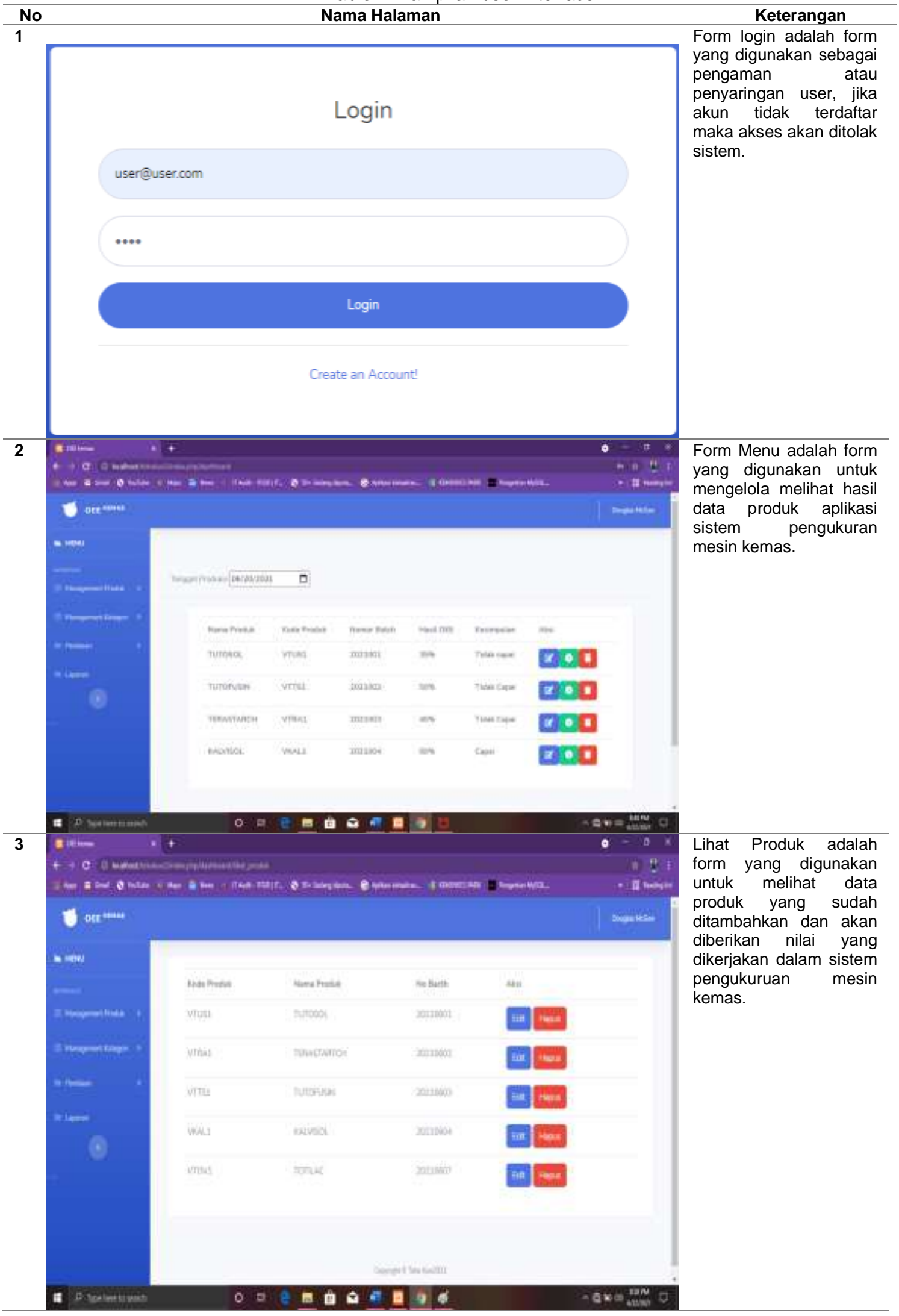




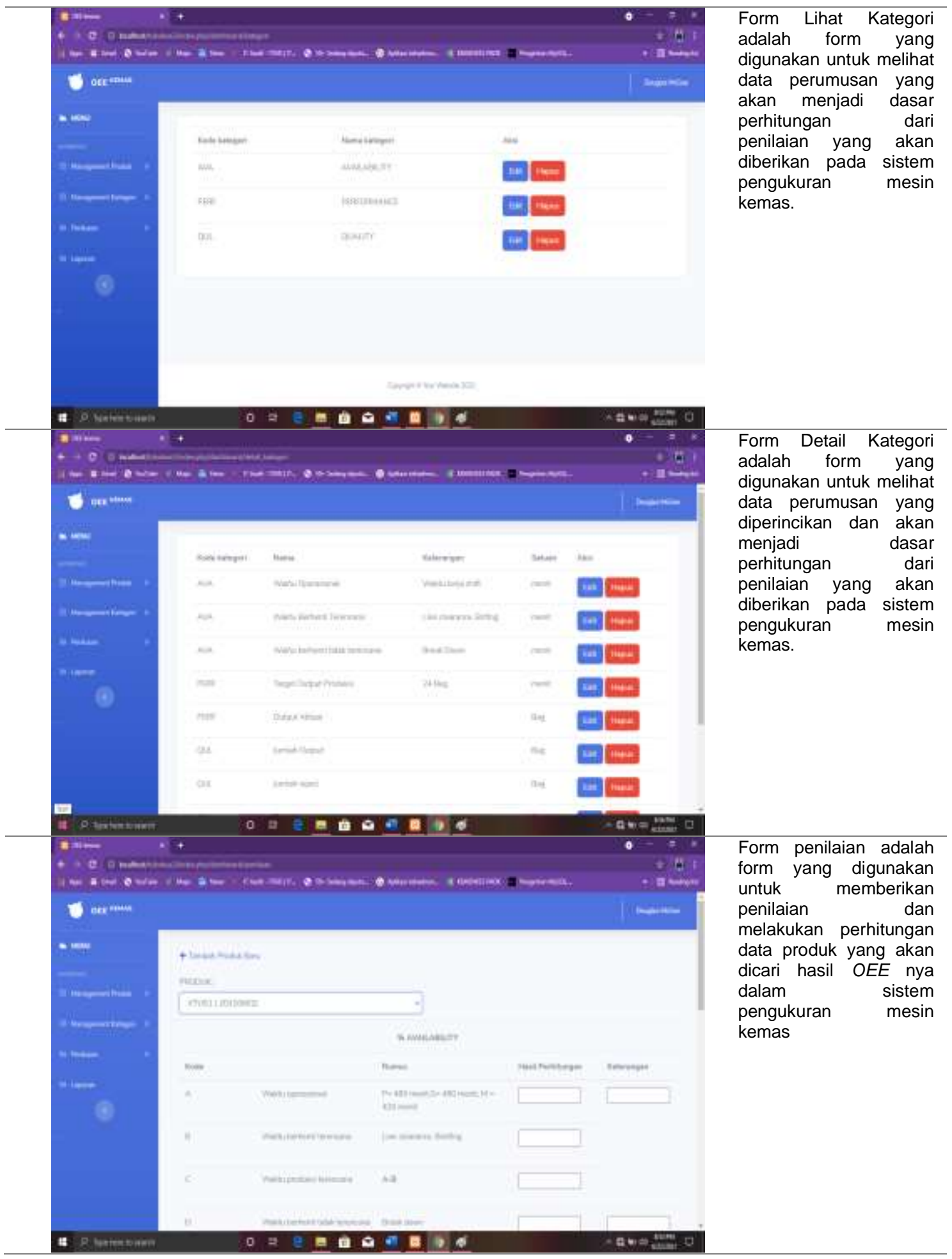




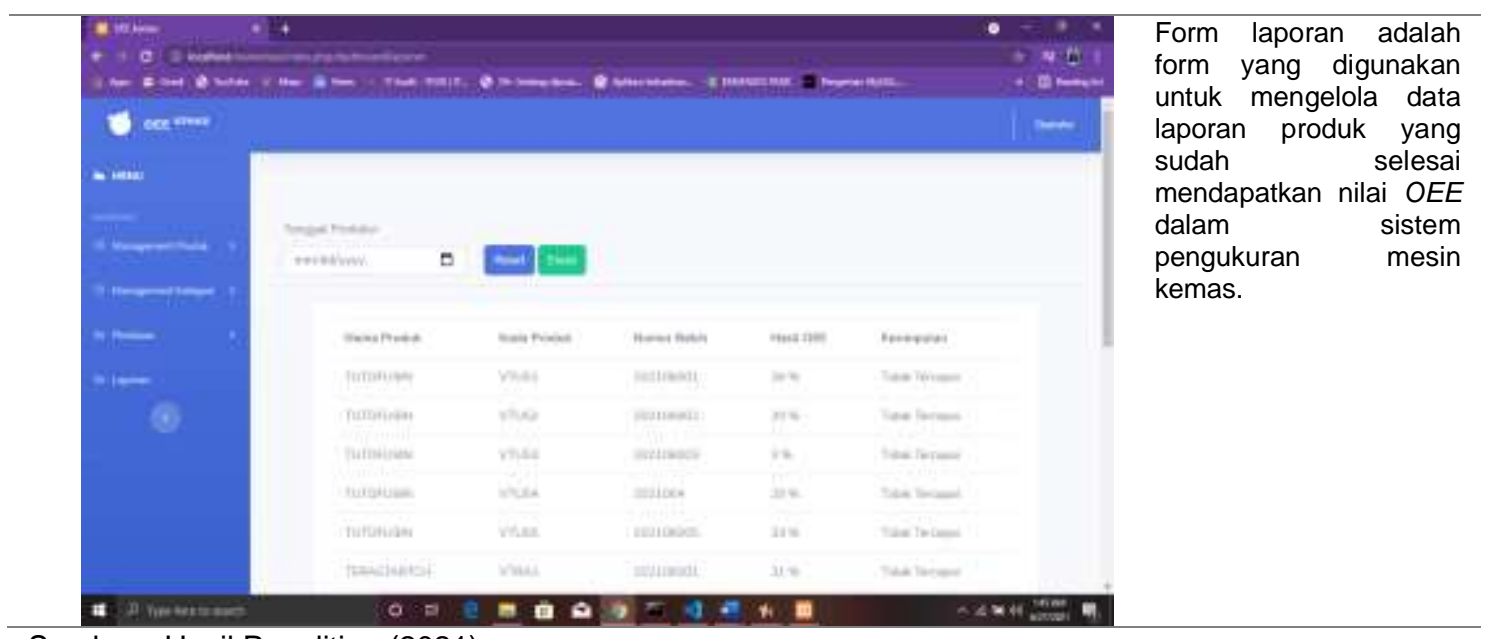

Sumber : Hasil Penelitian (2021)

\section{Kesimpulan}

Setelah melakukan penelitian pada PT Finusolprima Farma Internasional, maka dihasilkan sebuah aplikasi yang merupakan bentuk dari pembuatan sistem informasi pada PT Finusolprima Farma Internasional saat ini. Maka dihasilkan sebuah aplikasi yang merupakan bentuk dari perubahan sistem perhitungan ke efektifan mesin kemas yang selama ini masih dilakukan verifikasi berkas secara tertulis menjadi berbasis komputer. Setelah penelitian tersebut, maka dapat disimpulkan :1). Bahwa pengisian OEE yang dilakukan oleh operator kemas masih menggunakan sistem manual dengan cara pengisian masih melalui media tulis yang menggunakan formulir sebagai alat transaksi data. 2). Dengan adanya sistem informasi penerimaan karyawan baru dapat mengolah data pelamar di database sehingga data pelamar tidak menumpuk di lemari arsip. 3). Tercapainya keakuratan dalam membuat laporan karena sudah terhitung secara otomatis dari sistem.

\section{Daftar Pustaka}

[1] D. Suryana, Sistem Teknologi Informasi Jilid 3: Sistem Informasi Penggajian Karyawan. Bandung: CreateSpace Independent Publishing Platform, 2012.

[2] J. S. P. Tyoso, Sistem Informasi Manajemen. Yogyakarta: Deepublish, 2016.

[3] S. H. Syafizal, Analisis Data untuk Riset Manajemen dan Bisnis. Medan: USUpress, 2010.

[4] J. Abadi, Reniana, and P. Orllin Bertha, Buku Ajar Pengukuran Dan Instrumentasi. Yogyakarta: Deepublish, 2020.

[5] Qamar Nurul et al., Metode Penelitian Hukum (Legal Research Methods). Makassar: CV. Social Politic Genius (SIGn), 2017.

[6] Y. Firmansyah and U. Udi, "Penerapan Metode SDLC Waterfall Dalam Pembuatan Sistem Informasi Akademik Berbasis Web Studi Kasus Pondok Pesantren Al-Habib Sholeh Kabupaten Kubu Raya, Kalimantan Barat," J. Teknol. dan Manaj. Inform., vol. 4, no. 1, 2017, doi: 10.26905/jtmi.v4i1.1605.

[7] Anhar, Panduan menguasai PHP \& MySQL Secara Otodidak. Jakarta: PT.TransMedia, 2010.

[8] J. Simarmata, Rekayasa Web. Yogyakarta: Andi, 2010.

[9] U. Rusmawan, Teknik Penulisan Tugas Akhir dan Skripsi Pemrograman. Jakarta: Elex media komputindo, 2019.

[10] G. W. Sasmito, "Penerapan Metode Waterfall Pada Desain Sistem Informasi Geografis Industri Kabupaten Tegal," J. Inform. Pengemb. IT, vol. 2, no. 1, pp. 6-12, 2017. 